\title{
The Conformity Level of Income Tax Accounting In Jordan with the Requirements of the International Accounting Standard IAS (12) in Terms of Taxable Temporary Differences' Recognition
}

\author{
Ahmad Adel Jamil Abdallah ${ }^{1}$ \\ ${ }^{1}$ Accounting Department, Faculty of Economic and Administrative sciences, Al-Zaytoonah University of Jordan, \\ P. O. Box: 144128, Amman 11814, Jordan
}

Correspondence: Ahmad Adel Jamil Abdallah, Accounting Department, Faculty of Economic and Administrative sciences, Al-Zaytoonah University of Jordan, P. O. Box: 144128, Amman 11814, Jordan. E-mail: Ahmad.Ade1@zuj.edu.jo

Received: March 13, 2017

Accepted: April 10, $2017 \quad$ Online Published: April 12, 2017

doi:10.5539/ibr.v10n5p51

URL: https://doi.org/10.5539/ibr.v10n5p51

\begin{abstract}
The present study aimed to measuring the conformity level of income tax accounting in Jordan with the requirements of ISA (12), and because of increasing to apply the international standards by local and foreign companies in Jordan and Jordanian legislations it's appear gap between the accounting profit and the tax profit caused Taxable temporary and permanent differences. The study seeks to achieve set of goals represented by studying and analyzing the compatibility level of income tax accounting by a questionnaire was distributed to 100 income and sales auditors working in the senior and moderate Taxpayers, directorates 85 questionnaires were retrieved and eighty were valid for the study's purposes, the major results that is the study found the income tax accounting in Jordan does not adhere to the requirements of most of the international accounting standards as there were no presentation to the financial statements, and There was no recognition of Taxable temporary differences and deductible temporary differences (the differences between accounting profit and taxable profit) in the income tax accounting in Jordan.
\end{abstract}

Keywords: income tax accounting, ISA (12) requirements, taxable temporary differences

\section{Introduction}

The concept of tax has been developed as a result of the political, social and economic developments and it is no longer limited to the process of providing the treasury with money that was spent on the country's needs and requirements but it aimed to achieve justice among the people. The taxes which were imposed according to the people's financial capacity seek to reduce the gap between the society's layers. Accordingly, the temporary Income Tax Law Number 34 of 2014 was issued to reduce Tax rates on the companies and increase the individuals' ratio of exemptions to help them face economic circumstances. Significance of the study that there is a need to set specific procedures to treat the mechanism of the tax accounting on income in Jordan through developing the tax accounting on income in Jordan according to the international accounting standards requirements so as to reduce the gap between the accounting profit and taxable profit and to enhance trust between taxable management and taxpayers.

\subsection{Problem of the Study}

As a result of the increase in the companies that followed the international accounting standards in Jordan, and more foreign companies applied these standards in addition to calculation of the tax profit according to the Jordanian tax legislations, there was a great gap between the accounting profit and the tax profit caused Taxable temporary and permanent differences which were treated according to the international accounting standard (12) requirements. This study seeks to answer the following questions:

1. What is the conformity level of income tax accounting in Jordan with the requirements of the international accounting standards?

2. What is the conformity level of income tax accounting in Jordan with the requirements of the international accounting standards? 


\section{Objectives of the Study}

This study seeks to achieve set of goals represented by studying and analyzing the compatibility level of income tax accounting in Jordan and the requirements of the International Accounting Standard (IAS) and the compatibility level of income tax accounting in Jordan and the requirements of the International Accounting Standard IAS (12) in terms of recognition of Taxable temporary differences.

\section{Limitations of the Study}

This study is limited to the senior and moderate taxpayer's directorates because most of the companies applied international accounting standards are under the responsibility of these directorates. Also this study was not applied on the firms' financial managers because they were not aware enough of the temporary tax income law (No.34) for the year 2014which has been effective since 1-1-2015.

\section{Previous Studies}

1. Peculiarities of the Application of Income Tax Standards by the Subsidiary Company in the Russian Accounting Practice. (Ermakova \& Gudshatullaeva, 2016)

The study aimed to analyze the application practice of the local tax standard in Russia on accounting of settlements on income tax" (AR 18/02) and the standard's compatibility with the standards of International Accounting Standards (IAS) 12 "Income taxes" when preparing the consolidated statements. Many methods of logical-semantic analysis and synthesis were used to collect data. Results revealed parallel problems in the application of the Russian and international accounting standards. The study recommended the necessity of providing unified financial statements suit the local and the international standard in addition to reform the Russian local accounting system.

\section{The adoption of 'International Accounting Standard (IAS) 12 Income Taxes': Convergence or divergence with} local accounting standards in selected ASEAN countries? (Yapa \& others, 2015)

This study investigated socio-economic impact of the application of International Financial Reporting Standards (IFRS) with the national standards in some chosen countries. The study was applied in two stages: The first stage examined the impact of the IFRS standards on Singapore and Malaysia. The first stage's results showed the respondents' reservations about adopting IFRS which include increases of foreign investment and equity cost reductions. While in the second stage, many studies were conducted about the possibility of applying IAS12 Income Taxes as these taxes are considered the starting point of tax conformity and the major component of the financial statement. A questionnaire was prepared and distributed to the respondents to identify and investigate the challenges facing practitioners that apply this international standard in Australia. No results were stated because the instrument was distributed to those who are specialized in tax and who are not.

3. Harmonizing Corporate Income Taxes in the European Community: Rationale and Implications.(McLure \& Charles, 2008)

The article discussed tools of taxation system in European Community, which depend on varied accounting system and arm's length pricing, the features appear in integration and formula distribution like that used by United States and (and some provinces in Canada), the favorable features of such a system, the complexity because of income flows in and out from European Countries, and the inclusion of harmonization, for both members of European Countries and non- European Countries members, the results indicate that all of European Countries have harmonized system (like Canada), there will be greater consolidation of government taxes on corporate income in the United States and, such as some other countries taxes but various of Canada's system. The study concluded that adopting all the aspects of the tax procedures requires the agreement of all the members of EU but few of these countries can harmonies in the application process of this standard.

\section{Hypotheses of the Study}

1. There were no differences between the conformity levels of income tax accounting in Jordan with the requirements of the International Accounting Standard (IAS).

2. There were no differences between the conformity levels of income tax accounting in Jordan with the requirements of the International Accounting Standard IAS (12) in terms of recognition of Taxable temporary differences.

\section{Literature Review}

\subsection{Tax System in Jordan}

The tax- system differs from one country to another as a result to the political, social and economic situations but 
the major goal of any tax-system is to achieve the social and economic systems' goals which are changing from time to time to suit the country's developments. The tax system in Jordan passed by the following stages (Noor \&others, 2008, pp. 39-42)

The first Jordanian income law was issued in the first of April in 1933 and it was limited to the income of the public and private sectors of the salaries. Later, the Ministry of Finance established an income section to implement the income law provisions and more developments continue till the present.

\subsubsection{The Differences and Similarities between the Financial Accounting and the Taxable Accounting}

The financial accounting is the profit organization's preparation of the financial reports for the benefit of the firms' managers, investors, creditors, and tax authorities. While the taxable accounting aims at preparing the financial reports and identifying the firm's income to determine the tax amount that should be paid according to the country's tax laws. It is true that both financial accounting and the taxable accounting share some similarities in the general frame as financial statements preparation, book-keeping and in the fields of expenses and revenues. At the same time, they are inconsistent with identifying the concept on income as it is illustrated later in the study of (Abo-Nasar, 2012. pp. 30-31).

\subsubsection{Differences between Net Income and Taxable Income}

Net income represents the income after all revenues and expenses for the period are considered. (Kieso \& others, 2016, p. 154) income defined as growing in economic benefits through the financial period by inflows or improvements in assets or a decrease in liabilities leads to an increase in owner equity (Kieso \& others, 2016, p. 146). Expenses defined as Reduction in economic benefits through the financial period by outflows or lowering of assets or increases in liabilities leads to a decreases in owner equity (Kieso \& others, 2016, p. 46). Depend on the previous definitions the net income can define as the different between total revenues and total assets of the company. The definition of tax income varies in different legislations but the comprehensive definition is: "the income is every cash purchasing power flows periodically during a specific period of time". This definition may extend to include capital and accidental gains which are known as: theory of budget or enrichment (Bdewi, 2005, p. 14)

The Jordanian income tax law, article 2 defined the taxable income as everything remains of the gross income after the minus of all allowable expenses and deductions in addition to the carried forward losses from previous tax periods and personal exemptions plus donations respectively (Income Tax Law, 2014, p. 55). The income before income tax is defined as: "Income before income tax compute by deducting interest expense (often referred to as financial cost) from income from operations (Kieso \& others, 2016, p. 154)

\subsection{The International Accounting Standards Relevant To the Study}

\subsubsection{IAS (1) Presentation of Financial Statements}

This Standard describes the basis for presentation of general purpose financial statements, to ensure comparability both with the financial statements of entities for previous periods and with the financial statements of other entities. (IFRS/red book, 2017, p. 562) Through the field study, the researcher seeks to identify the extent to which tax accounting on income in jordan is committed to the requirements of the international accounting standard (1) concerning financial statements presentation and disclosure of the notes with these statements.

\subsubsection{IAS (2) Inventory}

The objective of this Standard is to describe the accounting treatment for inventories. The essential issue in accounting for inventories is the amount of recognized cost as an asset and carried forward until the related revenues are recognized (IFRS/red book, 2017, p. 615).

This standard requires the inventory to be measured at net realizable value and thus the conformity of the tax accounting on income in Jordan with the requirements of the international accounting standard 2 will be identified or it will be treated according to another basis.

\subsubsection{IAS (8) Accounting Policies, Changes in Accounting Estimates and Errors}

This Standard describe the criterions for selecting and changing accounting policies, together with the accounting treatment and disclosure of changes in accounting policies, accounting estimates and corrections of errors.

This standard (8): requires recognition, measurement and presentation of the changes in the accounting policies. Accordingly, the conformity of the tax accounting on income in Jordan with recognition, treatment and 
disclosure of changes in the policies is a necessity (IFRS/red book, 2017, p. 659).

\subsubsection{IAS (16) Property, Plant and Equipment}

This Standard is related to the accounting treatment for property, plant and equipment so that users of the financial statements can discern information about an entity's investment in its property, plant and equipment and the changes in such investment.

The international accounting standard 16 requires the recognition of the assets, the determination of their carrying amounts and the depreciation charges and impairment losses to be recognized in relation to them.

This standard requires the recognition of the profits of fixed assets sale as the difference between the values of the received receipt whether they were in cash or in kind with the fair value and the assets book value in tax accounting on income according to the international accounting standard (16) (IFRS/red book, 2017, p. 826)

\subsubsection{ISA (18) Revenue}

The objective of this Standard is to prescribe the accounting treatment of revenue arising from certain types of transactions and events. This standard requires the recognition of the revenue of selling the goods when they are sold in addition to the agreement with the buyer not to gain its value unless they were sold by the buyer to other parties. The study seeks to identify the conformity of the income tax accounting in Jordan with this standard's requirements (IFRS/red book, 2017, p. 888)

\subsubsection{ISA (19) Employee Benefits}

The objective of this Standard is to prescribe the accounting and disclosure for employee benefits. This standard allows reduction of the retirement expenses according to a specified benefits plan. And this study aims to identify if income tax accounting in Jordan allows reduction of the retirement expenses according to a specified benefits plan or if it requires payment of these expenses before being approved (IFRS/red book, 2017, p. 912)

\subsection{International Accounting Standard IAS (12): Income Taxes}

The differences between the financial accounting and the taxable legislations in treating revenues and expenses are divided in two categories:

\subsubsection{Temporary Differences}

There are timing differences in the recognition of revenues and expenses between taxes and the tax legislations. For example, the revenue of a leased property which is subjected to income tax in 2014 has to be recognized in 2015 according to the standards of accounting and financial reporting. In some countries, revenue is subjected to income tax when its value is received cash whereas this revenue is recognized according to the international accounting and financial reporting standards based on revenue recognition.

\subsubsection{Permanent Differences}

They are the permanent differences between the financial accounting and tax legislations in recognizing some revenues and expenses. Some of these expenses, for instance, are not recognized in some countries at all; they are dispensed from the income tax permanently, either for social or economic reasons whereas these expenses should be decreased and the income represents revenue that should be recognized according to the financial accounting (Abo-Nasar, 2012, p. 210)

\subsubsection{Objective}

The objective of this Standard is to prescribe the accounting treatment for income taxes. The principal issue in accounting for income taxes is how to account for the current and future tax consequences of:

1. The future recovery (settlement) of the carrying amount of assets (liabilities) that are recognized in an entity's balance sheet; and

2. Transactions and other events of the current period that are recognized in an entity's financial statements (IFRS/red book, 2017, p.729)

\subsubsection{Scope}

This Standard shall be applied in accounting for income taxes. Income taxes include all domestic and foreign taxes which are based on taxable profits. Income taxes also include taxes, such as withholding taxes, which are payable by a subsidiary, associate or joint venture on distributions to the reporting entity.

This Standard does not deal with the methods of accounting for government grants (IAS 20 Accounting for Government Grants and Disclosure of Government Assistance) or investment tax credits. However, this Standard 
does deal with the accounting for temporary differences that may arise from such grants or investment tax credits (IFRS/red book, 2017, p.729)

\subsubsection{Definitions}

These terms are used in ISA (12) with specified meanings:

Accounting profit are profit or loss for accounting period before subtract taxes expenses.

Taxable profits (tax loss) are profits (losses) for accounting period, which specified accordance to the regulations set by taxation authorities, when income taxes are recoverable.

Tax expense (tax income) the total amount used to determine the profits or losses for accounting period in all aspects of current tax and deferred tax.

Current tax amount of income taxes recoverable (payable) to all aspects of the taxable profits (losses) for accounting period.

Deferred tax liabilities: the total amounts of income taxes payable in next accounting periods to all aspects of taxable temporary differences.

Deferred tax assets are the total amounts of income taxes recoverable in next accounting periods to all of the following aspects:

(a) Deductible temporary differences;

(b) Not used tax losses; and

(c) Not used tax credits.

Temporary differences Temporary differences: the differences between the adjusted carrying amount of the asset or liability shown in the statement of financial position and the tax basis used to calculate it, these differences may be:

(a) Taxable temporary differences, are temporary differences that will result in taxable amounts when determining the taxable profit (tax loss) for the next financial periods when the recoverable or adjusted amount of the carrying amount of the asset or liability; or

(b) Deductible temporary differences, these are temporary differences that will result in deductible amounts when determining the taxable profit (tax loss) for future periods when the carrying amount of the asset or liability.

The tax base the tax base of an assets or liability: Is the amount attributed to that asset or liability for tax purposes (deductible), so the tax base of a particular asset is the amount to be deducted for tax purposes against any taxable economic benefits that will flow to the enterprise when the adjusted carrying amount is recovered. If the economic benefits are not taxable, Tax rate is equal to its adjusted carrying amount (carrying amount), in case of receiving revenue in advance the tax base of the liability is the carrying amount, deducted any revenues will not be taxable in next accounting periods (IFRS/red book, 2017, p. 730)

6.4 Tax Expense (Tax Income) Comprises Current Tax Expense (Current Tax Income) and Deferred Tax Expense (Deferred Tax Income)

6.4.1 Accounting Treatments Accordance to ISA (12)

\section{Recognition of current Tax Liabilities and current Tax Assets}

If the amount paid or payable to the Income Tax Department for current and previous income tax is less than the income tax calculated, the difference should be recognized as a liability. If the amount paid or payable for the current period and prior periods is greater than the calculated income tax, The increase is recognized as an asset.

\section{Recognition of Deferred Tax Liabilities and Deferred Tax Assets (Taxable Temporary Differences)}

Tax liabilities should be recognized for all temporary tax differences, but the Standard except to several cases of recognition of temporary differences as liabilities:

(a) The primary goodwill recognition; or

(b) Unamortized goodwill for tax purposes; or

(c) The primary recognition in transaction for an asset or liability which:

(i) Is not a business combination; and

(ii) At the transaction time, do not affect the accounting or taxable profit (loss). However, for taxable temporary 
differences related to investments in branches, subsidiaries, and shares in jointly controlled entities are to be recognized as deferred tax liabilities (IFRS/red book, 2017, pp. 733-734)

\section{Calculation and Measurement of Deferred Tax Assets and Liabilities}

The procedure to calculate the gross deferred tax provision (i.e., before determines whether the probability of realizing the deferred tax asset) after identified exempt temporary differences and non-use of tax losses and tax credits, the procedure is as follows:

a. Separate the temporary differences into two types taxable and deductible. This step is important because accordance to IAS 12 only recognized deferred tax assets which probable of being realized, vice versa all deferred tax liabilities must full recognition.

b. Collect information about the deductible temporary differences, especially the net losses, and credit carry forwards that have expiration dates.

c. Measure the accumulated taxable temporary differences effect by applying the proper expected tax rates.

d. Finally, measure the deductible temporary differences tax effects, including net losses carryforwards (IFRS/Wiley, 2015, p.784)

\section{Methodology \& Procedures}

\subsection{Population \& Sample of the Study}

The population of the study which consisted of 250 income and sales auditors working in the Senior and moderate Taxpayers directorates is the best category that is capable to answer the study's questions since they are expert in the field of auditing and accounting.

A random sample representing $40 \%$ of the population of the study was chosen. A questionnaire was built by the researcher and distributed to 100 respondents .Eighty five questionnaires were retrieved and eighty were valid for the study's purposes.

\subsection{Instruments of the Study}

The researcher collects data relying on the following resources:

- Secondary resources: the income Law, the international accounting standards, textbooks, Periodicals, researches and other related studies to this study's subject.

- Primary resources: a questionnaire was prepared by the researcher to collect data so as to testify the hypotheses.

- Data which were collected using questionnaire were analyzed statistically using SPSS to test the study's hypothesis.

\subsection{Design of the Study \& Statistical Treatment}

The descriptive analytic approach was used. The researcher, theoretically, addressed relevant aspects concerning the income legislations and the international accounting standards. Furthermore, a questionnaire was prepared, distributed and analyzed statistically. Results were concluded and recommendations were proposed. The following statistical methods were used:

- Internal Consistency Coefficient (cronbach's alpha)

- Means

- Standard deviations

- T-test

\subsection{The Instrument's Reliability}

To verify the instrument's reliability, the internal consistency coefficient using Cronbach Alpha was used as it is illustrated below. 
Table 1. Internal Consistency Coefficient (Cronbach Alpha)

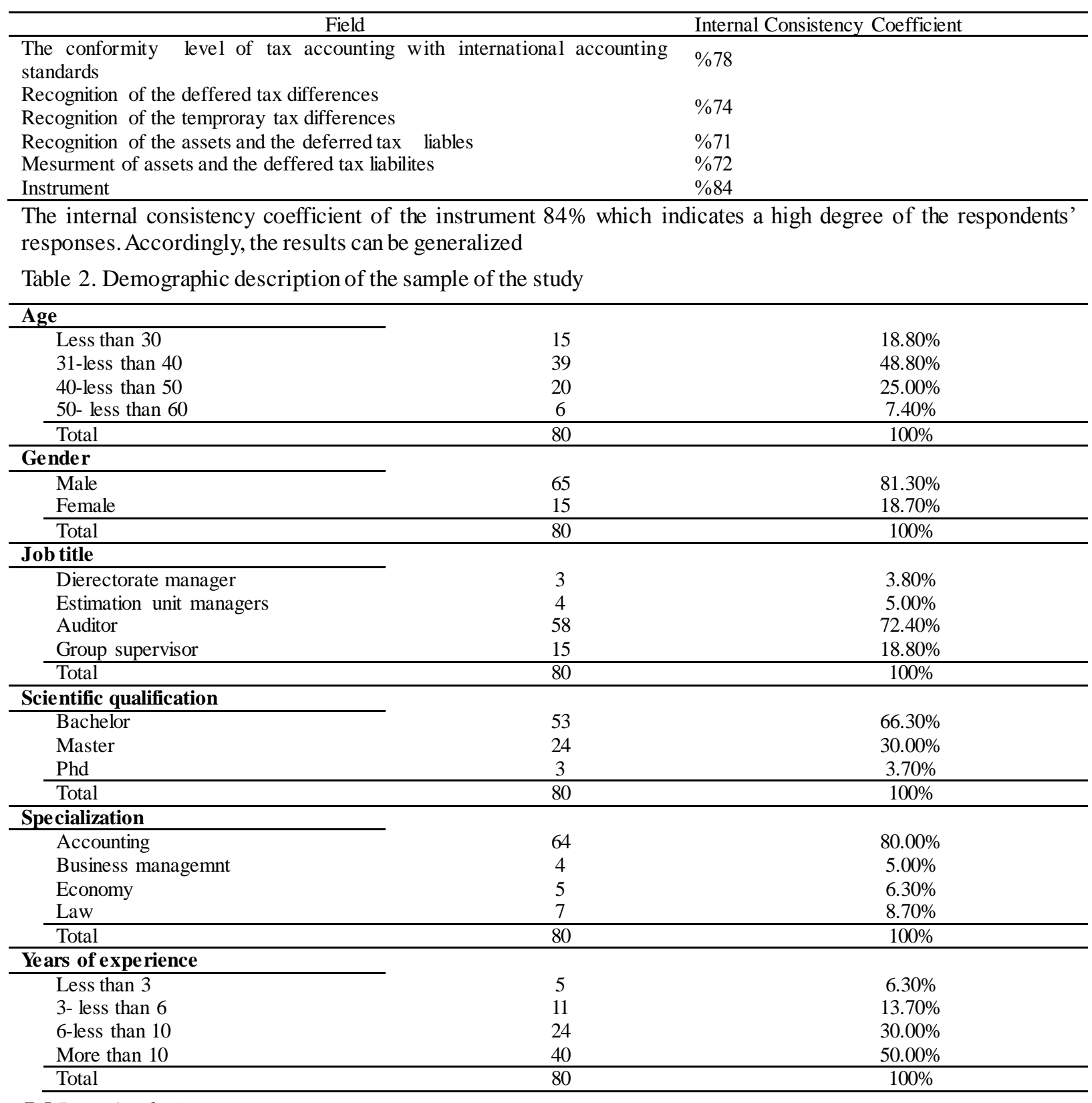

\subsection{Data Analysis}

To develop the tax accounting on the income in Jordan according to the international accounting standards' requirements, a questionnaire was prepared and distributed to the sample to collect data which were analyzed statistically. Fifth -Lickert scale was adopted: strongly agree (5), agree (4), neutral (3), disagree (2), strongly disagree (1) to correct the students' responses. The highest grade was (160) and lowest was (32).

For the lack of standard distribution, the questionnaire items' means were classified as follows:

$$
\begin{array}{ll}
\text { 1- } & \text { Less than } 2.5 \quad \text { (low) } \\
\text { 2- } & \text { Less than 3.5 (moderate) } \\
\text { 3- } & \text { Between 3.5- } 5 \text { (high) }
\end{array}
$$

\subsection{Testing Hypotheses of the Study}

\subsubsection{First Hypothesis}

"There were no differences between the compatibility of income tax accounting in Jordan and the international accounting standards' requirements" 
To verify the validity of this hypothesis, the means and standard deviations of the items concerning the commitment of income tax accounting in Jordan to the international accounting standards' requirements as it is illustrated in the following table

Table 3. Means and standard deviations of the items concerning the commitment of income tax accounting in Jordan to the international accounting standards' requirements

\begin{tabular}{|c|c|c|c|c|c|}
\hline Rank & $\mathrm{N}$ & Items & M & Std & Sig. \\
\hline 1 & 5 & $\begin{array}{l}\text { Recognition of calculating fixed assets with fair value according to international } \\
\text { accounting standard (16) in income tax accounting. }\end{array}$ & 2.29 & .56 & Low \\
\hline 2 & 4 & $\begin{array}{l}\text { The income tax accounting in recognition, measurement and presentation of the } \\
\text { change in the accounting policies are consistent retrospectively with the requirements } \\
\text { of the international accounting standard }(8)\end{array}$ & 2.14 & .63 & Low \\
\hline 3 & 2 & $\begin{array}{l}\text { Tax accounting on income requires notes' attachment to the financial statements according } \\
\text { to the international financial accounting statement (1) }\end{array}$ & 2.10 & .41 & Low \\
\hline 3 & 6 & $\begin{array}{l}\text { In income tax accounting, there is no recognition of the revenue of selling the goods when } \\
\text { they are sold in addition to the agreement with the buyer not to gain the goods value unless } \\
\text { they are sold by the buyer to other parties according to international accounting standard } \\
18 \text {. }\end{array}$ & 2.10 & .52 & Low \\
\hline 4 & 1 & $\begin{array}{l}\text { Income Tax accounting requires presentation of financial statements according to } \\
\text { international accounting standard (1) }\end{array}$ & 2.09 & .48 & Low \\
\hline 5 & 8 & $\begin{array}{l}\text { Income tax accounting allows reduction of retirement's expenses following specified } \\
\text { benefits plan according to international accounting standard } 19\end{array}$ & 2.05 & .57 & Low \\
\hline 6 & 3 & $\begin{array}{l}\text { There is compatibility between income tax accounting and the requirements of the } \\
\text { international accounting standard(2) in terms of valuation of inventory by } \\
\text { Net Realizable Value }\end{array}$ & 2.01 & .44 & Low \\
\hline & 7 & $\begin{array}{l}\text { Recognition of the profits of fixed assets sale as the difference between the value of the } \\
\text { received receipt whether they were in cash or in kind with the fair value and the assets } \\
\text { book value in tax accounting on income according to the international accounting standard } \\
\text { (16) }\end{array}$ & 1.91 & .51 & Low \\
\hline & & $\begin{array}{l}\text { The conformity Level of income tax accounting in jordan with the requirments with the } \\
\text { international accounting standards }\end{array}$ & 2.08 & .35 & Low \\
\hline
\end{tabular}

The previous table showed that the means ranged from 1.91 to 2.29.item (5): " recognition of fixed assets with fair value according to the international accounting standard 16" came first with a mean (2.29) while item(7): "recognition of profits of fixed assets purchase in the difference between the values received whether it was cash or not with fair value and the assets book value in the income tax-accounting according to the international accounting standard (16)" came last with a mean (1.91) and the mean of the conformity level of the income tax accounting in Jordan with the international accounting standards' requirements was (2.08).

\section{a. Testing First Hypothesis}

The mean was compared with the assumed mean (3) using t-test as it is illustrated below.

Table 4. Testing the first hypothesis using t-test

\begin{tabular}{|c|c|c|c|c|}
\hline & $\mathrm{M}$ & Std & $\mathrm{T}$ & Sig. \\
\hline $\begin{array}{l}\text { Conformity of income tax accounting in } \\
\text { Jordan with the requirements of the } \\
\text { international accounting standards }\end{array}$ & 2.08 & .35 & 18.649 & .000 \\
\hline
\end{tabular}

The previous table showed that the mean (2.05) was less than the standard mean (3) with a standard de viation (0.35). The $\mathrm{t}$-value which was (18.649) was considered statistically significant at $(\mathrm{a} \leq 0.05)$ and therefore the null hypothesis was rejected and the alternative one was accepted: "there were differences between the conformity of income tax accounting in Jordan with the requirements of the international accounting standards.

Second hypothesis : " there were no differences between the conformity level of income tax accounting in Jordan with the requirements of the international accounting standard in terms of permanent and temporary differences",

To verify the validity of this hypothesis, the means and standard deviations of the relevant items to recognition of the temporary and permanent differences according to international accounting standard( 12) were calculated as it is illustrated below. 
Table 5. Means and standard deviations of the relevant items to recognition of the temporary and permanent differences according to international accounting standard (12)

\begin{tabular}{|c|c|c|c|c|c|}
\hline Rank & $\mathrm{N}$ & Items & $\mathrm{M}$ & Std & Sig. \\
\hline 1 & 7 & Recognitipon of the Deductible temporary differences & 2.19 & .55 & Low \\
\hline 2 & 1 & $\begin{array}{l}\text { Difference between the depreciation expense in the financial statements and the tax } \\
\text { deductible expenses causes taxable temporary differences }\end{array}$ & 2.09 & .46 & Low \\
\hline 2 & 6 & Recognition of amount of taxable temporary differences & 2.09 & .56 & Low \\
\hline 3 & 5 & Bad debt causes temporary taxable differences & 2.04 & .54 & Low \\
\hline 4 & 2 & $\begin{array}{l}\text { Differences between the book value of the doubtable debt and received value tax cause } \\
\text { temporary taxable differences }\end{array}$ & 2.01 & .46 & Low \\
\hline 4 & 3 & $\begin{array}{l}\text { Amounts withheld for the end service benefits' provision which were delayed for taxable } \\
\text { purposes till the employee's end of service cause temporary taxable differences }\end{array}$ & 2.01 & .49 & Low \\
\hline \multirow[t]{2}{*}{5} & 4 & $\begin{array}{l}\text { Stagnant inventory which were listed in the financial statements but they were not } \\
\text { approved, cause temporary taxable differences }\end{array}$ & 1.97 & .48 & Low \\
\hline & & $\begin{array}{l}\text { Recognition of permenant and temproray differences according to the internatioanl } \\
\text { accounting standard(12) }\end{array}$ & 2.05 & .16 & Low \\
\hline
\end{tabular}

The means as illustered in the previous table ranged (1.97 -2.19) as item(7): " recognitipon of the Deductible temporary differences" came first with the highest mean( 2.19) while item(4): "Stagnant inventory which were listed in the financial statements but they were not approved, cause temporary taxable differences" come last with the least mean (1.97). Additionally, the recognition of the permenant and temproray taxable differences according to the international accoutning standard(12) was 2.05.

b. Testing Second Hypothesis

The mean was compared with the assumed mean (3) using t-test as it is illustrated below.

Table 6. Testing second hypothesis using t-test

\begin{tabular}{|c|c|c|c|c|}
\hline & $\mathrm{M}$ & Std & $\mathrm{T}$ & Sig. \\
\hline $\begin{array}{l}\text { Recoginition of temprorary and perminant } \\
\text { differences according to requirements of } \\
\text { international accounting standard } 12\end{array}$ & 2.05 & .16 & 53.876 & .000 \\
\hline
\end{tabular}

The previous table showed that the mean (2.05) was less than the standard mean (3) with a standard de viation (0.16). The t-value which was (53.876) was considered statistically significant at $(a \leq 0.05)$ and therefore the null hypothesis was rejected and the alternative one was accepted: "there were differences between the compatibility of income tax accounting in Jordan and the requirements of the international accounting standard 12 in terms of Recoginition of temprorary and perminant differences.

\section{Results \& Recommendations}

\subsection{Results}

Based on the previous discussion, we note that the income tax accounting in Jordan does not commit to the international accounting standards' requirements with an exception some of them. Accordingly, there were temporary tax differences in auditing the companies that are committed to international accounting standards knowing that these companies were not charged of tax evasion and this will make a big gap between these companies and the Income and Sales Tax Department. The performance of Income and Sales Tax Department will be affected negatively and the firms feel confused because of the tax differences' treatment which resulted from the application of tax accounting on these firms' incomes. Based on the field study, the researcher came up with the following results:

The income tax accounting in Jordan does not adhere to the requirements of most of the international accounting standards as there were no presentation to the financial statements and any attached notes with them according to the requirements of the international accounting standard (1): presentation of financial statements.

Income tax accounting in Jordan requires evaluating inventory with cost or market value but not as stated in international accounting standard (2) where inventory is evaluated by net realizable value.

The income tax accounting in Jordan requires recognition of fixed assets and does not allow reevaluation of the assets with fair value according to the international accounting standard (16): property, plant and equipment.

There was no recognition of Taxable temporary differences and deductible temporary differences (the differences between accounting profit and taxable profit)t in the income tax accounting in Jordan according to the international accounting standard (12):income taxes. 


\subsection{Recommendations}

Depending on the previous results, the researcher recommended the following:

The income tax accounting in Jordan should commit to the requirements of the international accounting standard (8) "the criteria for selecting and changing accounting policies, with the accounting treatment and disclosure of changes in accounting policies, changes in accounting estimates and errors corrections ".

The income tax accounting in Jordan should adhere to the requirements of the international accounting standard (1): Presentation of Financial Statement in terms of presenting financial statements and attaching notes with them.

The income tax accounting in Jordan should adhere to the requirements of the international accounting standard (2): Inventories in terms of evaluating the inventory based on net realizable value.

The income tax accounting in Jordan' recognition of the temporary tax differences according to international accounting standard 12: income taxes.

The income tax accounting in Jordan commits to international accounting standard 16: property, plant and equipment in terms of recognition of sale fixed assets' profits as the difference between the values of the received receipt whether they were in cash or in kind with the fair value and the book value of the asset.

\section{References}

Abo-Nasar, M., \& Hmedat, J. (2012). Accounting Standards and International Financial Reporting, (3ed edition, pp30-31) National Library, Amman, Jordan.

Bdewi, M. (2005). Tax Accounting, (1 ${ }^{\text {st }}$ edition p14) Aldar Aljameiah, Alexandria, Egypt.

Chaudhry, A. etc. (2015) interpretation and application of International Financial Reporting standards, (p784) John Willy \& Sons, Inc.

Ermakova, N. A., \& Gudshatullae va, E. M. (2016). Peculiarities of the Application of Income Tax Standards by the Subsidiary Company in the Russian Accounting Practice. International Journal of Environmental \& Science Education, 11(13), 5873-5882.

Income Tax Law (34) for the year. (2014). p55, Amman, Jordan

International financial Reporting standards, IFRS/red book (2017). p562, London, United Kingdom

Kieso, D. E., Jerry, J. W., \& Terry, D. W. (2016). Intermediate Accounting, (16th Edition, p 154), John Willy \& Sons, Inc.

McLure, J., \& Charles, E. (2008). Harmonizing Corporate Income Taxes in the European Community: Rationale and Implications. NBER/Tax Policy \& the Economy (University of Chicago Press), 22, 151-195.

Noor, A., \& Adas, N. (2008). Taxes and its accountability, (2ed edition, pp39-42), Almaseerah for publishing, Amman, Jordan.

Yapa, P. W. S., Kraal, D., \& Joshi, M. (2015). The adoption of 'International Accounting Standard (IAS) 12 Income Taxes': Convergence or divergence with local accounting standards in selected ASEAN countries? Australasian Accounting Business \& Finance Journal, 9(1), 3-24. https://doi.org/10.14453/aabfj.v9i1.2

\section{Copyrights}

Copyright for this article is retained by the author(s), with first publication rights granted to the journal.

This is an open-access article distributed under the terms and conditions of the Creative Commons Attribution license (http://creativecommons.org/licenses/by/4.0/). 